\title{
MONGOLIA-US TRADE AND ECONOMIC RELATIONS AND COOPERATION
}

\author{
By Ts. Baatar Ph.D (Mongolia)
}

Mongolia and the USA are geographically distant countries, and so there are obvious restraints for developing relations and cooperation on a large scale. The two countries have developed relations before they established the diplomatic relations in 1987, since both sought to develop bilateral relations throughout the twentieth century. The foundation for developing intensive and efficient relations between the two countries was established as part of the globalization process. Our conception space and time has changed due to the current rapid progress in information technology and transport development. The broad possibilities to maintain relations and exchange information between the government and private organizations of two countries have increased rapidly.

Mongolian-American partnership is based on the shared values of democracy and free market economy services as important factors for the development of their relations. As a result of the political relations trade and economic relations and cooperation have expanded. Today a tendency appears for the further intensive development of relations. Businesspersons are expanding their activities in conformity with the global market economy. Investors from the USA are interested even more in cooperation in Mongolian mining sector.

Mongolia gives top priority to the relations established with the USA taking account of the country's weight and position in the international arena, and is a reason to consider it as one of the major pillars of the third neighbor concept.

Mongolia has been actively striving for deepening the relations and cooperation with the USA in recent years, judging that the relationship has a great important for strengthening Mongolia's democracy and market system, as well as expanding its external relations.

We can observe that the improved changes are occurring every year in our relations with the U.S. As a result, mutual trust between the two countries have been strengthened and Mongolia's position in the US foreign policy agenda has increased. In this way Mongolia considers the USA as a "strategic partner", and takes new steps and promotes active positions to enhance 
relations. There have been a number of significant visits. For instance, the President of the USA received the Mongolian Prime Minister (November 2001) for the first time even though the country was still in a difficult situation after the terrorist attack on September 11, 2001 - a clear demonstration of how the USA values highly the democratic changes in Mongolia and in its foreign policy. In January 2003 the President of Mongolia visited Washington DC and met the President of the USA and other high-ranking officials during his participation in the opening ceremony of the UN Literacy Decade campaign. The cooperation between the legislative powers of two countries has also intensified. Business meetings and visits of top-ranking delegations became regular events. The increasingnumber of meetings with leaders, members and other officials from the USA Congress for exchanging opinions has also been expanding cooperation. During these meetings the two sides unanimously agree that Mongolia-US relations are developing intensively, especially in the political sector. The importance of expanding the trade and economic cooperation has been expressed by the Mongolian side. Furthermore, Mongolia strongly supports all action of the USA against the international terrorism and promotes cooperation within Iraq rehabilitation operation. These activities are helping to increase our place in the USA foreign policy and have become one of the factors influencing improved relations between our countries.

Deputy Secretary of the State Richard Armitage paid a visit to Mongolia in the beginning of 2004. During his visit both sides discussed present relations between the two countries, and made progress several issues of current international relations. A joint statement on bilateral and regional cooperation between Mongolia and the USA was signed as a result of the meeting. Politically, the visit was very important since it was marked the first high level visit by American top-ranking official since that of Secretary of State, Madeleine K. Albright in 1998. The American side has expressed its determination to strengthen and expand cooperation between the two sides in all sectors. During Armitage's visit the Mongolian side requested an increased amount of scholarshipgrants from the USA. Following the Armitage visit, the Embassy of the USA officially announced that it will expend US\$ 500,000 in the scholarship program. Mongolians are gratified that the USA is paying more attention to the human capital serving as a starting point for Mongolian development by increasing their investment to this field. In a word, it is a clear evidence of the future driven investment. Human assistance has also been rendered through the US Peace Corps which also contributes to intellectual investment. American management 
has also been introduced into Mongolia. The Mongolian KHAAN bank narrowly escaped bankruptcy, regained its position, and became the most profitable and respected in a short time, thanks to the efforts of American banker Peter Morrow who manages it under contract. It is one of the visible results of introducing modern management into Mongolia's banking sector.

\section{Economic cooperation}

From the introduction of democracy and market economy into Mongolia, the USA has given strong support and today is one of the leading aid donors. TheUSA takes an active role in the annual consultative meetings of Mongolian assistance donors. At the moment almost every sector of the Mongolian economy is covered by American assistance and support. As the American government agency responsible for issues of the international aid, USAID plays a dominant role in rendering economic assistance, developing bilateral cooperation and ensuring implementation of aid programs.

USAID began to implement its aid programs in Mongolia in 1991 and has provided emergency assistance equal to US\$ 10 millions. As of 1998, the Agency gave Mongolia equipment and technology worth US\$ 50 millions for addressing the urgent matters. At the time USAID programs were usually directed to emergency food assistance and health sector needs. In addition, USAID makes contributions to deepening political and economic reforms.

In 2003 USAID promulgated the strategic guidelines on the cooperation for the next five years (2004-2008). Its main objectives are to continue support to Mongolia's sustainable economic development based on free market economic relations and ensuring capability of governance.

Also it strives to help Mongolia by providing a favorable environment for private investment. USAID assists an emerging market economy because of Mongolia's sustainable development and social welfare depend on domestic and foreign direct investment into the private sector, as well as export-oriented trade. Other activities run by USAID in Mongolia are dedicated to combating corruption, improving budget expenditure management, and providing economic opportunities in local areas. As statistics indicate, the private sector accounts for over 80 percent of Mongolian economy and GDP is at US\$ 1 billion. Per capita GDP amounts to US $\$ 450$ for a population of 2.4 million. American assistance is helping to raise the living standard of the population, and to increase per capita incomes. USA administration considers many factors in 
investment in Mongolia, stressing development and strengthening the market systemt.

These supports have resulted in the improvement of the investment and business environment, reduction of the public administration bureaucracy, implementation of reform in the taxation system, continuation of privatization of state property, sustaining the legislative and investment environment, and ensuring that the legal framework for attracting the foreign and domestic direct investment is improved in the above sectors.

The Government of Mongolia has declared at high level meetings that it would support cooperation with USAID as before in order to expand even more the relations and cooperation established with the USA in democracy, free market system, human rights, trade, investment, security, law implementation, culture, education, and other sectors.

The USA also is implementing the two-way programs on technical assistance appropriate to the development goals of Mongolia. One such example is Mongolia's eligibility for Millennium Challenge Account. The draft documents to be introduced to MCA were sent to Millennium Challenge Corporation. In these documents, which were developed with active participation of the nation's representatives and approved by the Government, are contained the main objectives and strategic goals of the suggested projects and programs. In the beginning of this year the delegation from the Corporation visited Mongolia in order to be acquainted with the Mongolia's present situation and to clarify the projects.

The main four sectors included business development, the National Council of MCA selected education, health and infrastructure as the other three.

\section{Mongolia-US trade relations}

In recent years both Mongolia-US economic cooperation and trade relations has been progressing significantly. The USA is not only one of the five leading investment countries in Mongolia, but also one of its large trade partners.

With regard to the legal frameworks of Mongolia-US trade relations, the two countries have concluded a bilateral trade agreement in 1991, an agreement on mutual protection and encouragement of investment in 1994. More recently, (July 2004) Mongolia and the U.S. concluded an agreement on development of trade and investment. Since 1990 more than 80 companies have been established 
in Mongolia with American investment and they have introduced investments equal to $\$ 38$ millions into the economy of the country. In the period 1996-2004 American investments grew by $\$ 2.6-10.5$ millions annually. In the last period, the amount of Mongolian exports increased by four times, largely consisting of knitted and woolen production. It also is closely associated with the US export quota on preferential tariff reductions set for Mongolian products. This quota expired in January 2005, and could result in a drastic decline in the amount of Mongolian exports to the USA. Thus there is a possibility that Mongolia-US trade will decrease. Notwithstanding this reason, it is important that the USA compensate these deficits by expanding cooperation in other directions. USA remains interested in introducing investments into Mongolia. But to succeed in competing for foreign investment, Mongolia will have to make itself more attractive to American investors through providing Government sustainability, eliminating bureaucracy and properly adhering to international agreements and standards. Currently, the USA is ready to make more investments in Mongolia. The following table shows how the trade of both countries has progressed in recent years.

\section{Mongolia-US trade (1999-2004)}

(In millions of US\$)

\begin{tabular}{|l|l|l|l|l|l|c|}
\hline & 1999 & 2000 & 2001 & 2002 & 2003 & $\begin{array}{c}2004 \\
\text { (As of September) }\end{array}$ \\
\hline Export & 78.0 & 130.2 & 144.5 & 165.7 & 142.9 & 113.6 \\
\hline Import & 31.5 & 28.4 & 14.9 & 23.4 & 23.5 & 34.8 \\
\hline
\end{tabular}

Source: Statistical Bulletin of Mongolia.

The table shows a tendency of annual growth in our exports to USA while imports from the USA fluctuate. As of September 2004 the combined trade turnover increased by US $\$ 148.4$ millions, or 30 percent compared to the previous year.

Over this period Mongolian exports to the USA reached US\$113.6 million. up 18.2 percent compared to the previous year.

The direct investment from USA tends to grow usually in the mining sector. It may be associated with the Minerals Law of Mongolia, which provides a favorable environment for the foreign investment.

Negotiations for a Free Trade Agreement with the U.S. is underway. An Agreement on Trade and Investment, a model agreement for the FTA was 
concluded in July 2004. In addition, representatives are working to conclude an "Agreement on Avoidance of Double Taxation". An FTA will be important for increasing and diversifying export goods, expanding investment, and reducing or eliminating tariffs.

Mongolia's woolen garment exports will be reduced due to the expiring annual quota of export textiles to USA at the end of 2004. Therefore, concluding a Free Trade Agreement with the USA remains an urgent need in order to explore other exports, increase trade, and expand American investment. 